\title{
Desain Dan Implementasi Penyeimbang Baterai Lithium Polymer Berbasis Dual Inductor
}

\author{
Darus Setyo Widiyanto, Heri Suryoatmojo, dan Soedibyo \\ Jurusan Teknik Elektro, Fakultas Teknologi Industri, Institut Teknologi Sepuluh Nopember (ITS) \\ Jl. Arief Rahman Hakim, Surabaya 60111 \\ e-mail: darus13@mhs.ee.its.ac.id; suryomgt@ee.its.ac.id; dibyosoe@gmail.com
}

\begin{abstract}
Abstrak - Baterai Lithium Polymer merupakan baterai yang banyak digunakan pada saat ini, baterai Lithium Polymer dapat mensuplai dengan arus yang tinggi hingga mencapai dua puluh kali kapasitasnya. Selain itu desain baterai Lithium Polymer lebih kecil dibangkan dengan baterai Lead Acid maupun Ni-CD dengan kapasitas yang sama. Akan tetapi baterai Lithium Polymer mempunyai beberapa kelemahan. Salah satunya yaitu dapat rusak jika overcharging dan over discharging. Pada alat alat tertentu sel baterai Lithium Polymer disusun secara seri untuk menaikkan tegangannya. Penyusunan sel baterai secara seri membuat perbedaan tegangan saat charging maupun discharging pada masing - sel baterai. Perbedaan tegangan tersebut menyebabkan sel baterai tidak terisi penuh secara bersamaan sehingga menyebabkan overcharging pada sebagian sel baterai. Hal ini menyebabkan rusaknya sel baterai dan bisa menyebabkan baterai meledak.

Pada penelitian ini akan didesain dan diimplementasikan Penyeimbang Baterai Lithium Polymer Berbasis Dual Inductor. Penyeimbang ini merupakan pengembangan dari Buck-boost converter dengan penambahan induktor dan flying capacitor .

Hasil implementasi menunjukkan bahwa penyeimbang baterai dapat menyeimbangkan tegangan tiga sel baterai dengan perbedaan tegangan yang tinggi. Disamping itu desain alat ini lebih sederhana dibandingkan dengan metode lain sehingga mudah untuk diaplikasikan.
\end{abstract}

Kata Kunci : Lithium Polymer, Dual Induktor, Penyeimbang Baterai

\section{PENDAHULUAN}

$\mathrm{P}$ ENGGUNAAN baterai lithium polymer semakin tinggi karena mempunyai banyak kelebihan seperti tegangan yang tinggi, kapasitas besar dengan ukuran fisik kecil, tidak ada efek memori, dan minim polusi. Umumnya pada peralatan berkapasitas besar dibutuhkan lebih dari satu baterai untuk catu dayanya. Baterai tersebut disusun secara seri atau pararel pada sebuah wadah khusus yang disebut battery pack.

Setiap sel baterai pada battery pack mempunyai karakteristik yang berbeda. Hal ini menyebabkan perbedaan waktu pengisian maupun pengosongan pada tiap sel baterai sehingga baterai tidak terisi penuh secara bersamaan. Jika ketidak seimbangan tersebut tidak dikontrol maka, akan berpotensi membahayakan sel baterai tersebut.

Untuk memperpanjang umur baterai dan sebagai pengaman baterai dibutuhkan alat penyeimbang (balancer) yang berfungsi untuk menyeimbangkan tegangan tiap sel baterai sehingga sel baterai terhindar dari overcharging. Berdasarkan aliran energi yang melalui sel baterai, proses penyeimbangan baterai dikategorikan dalam dua jenis, yaitu penyeimbang pasif dan penyeimbang aktif. Penyeimbangan secara pasif dilakukan dengan membuang muatan dari baterai yang bertegangan paling tinggi menggunakan resistordan transistor. Penyeimbang secara pasif mempunyai efisiensi nol, karena energi dari kelebihan muatan pada baterai diserap oleh resistor. Sedangkan pada penyeimbang aktif, energi dari baterai yang bertegangan lebih tinggi dapat dialirkan menuju baterai yang mempunyai tegangan lebih rendah, sehingga dapat meningkatkan efisiensi.

Penyeimbang Baterai Lithium Polymer Berbasis Dua Inductor merupakan penyeimbang aktif yang terdiri dari dua buah induktor, satu kapasitor, tiga diode, empat saklar frekuensi tinggi, dan sebuah switch array untuk mengalirkan energi dari sel baterai yang bertegangan lebih tinggi menuju baterai dengan tegangan yang lebih rendah. Sehingga dapat meningkatkan efisiensi dan mempersingkat waktu penyeimbangan karena energi dari sel yang bertegangan paling tinggi dapat dialirkan secara langsung menuju baterai yang mempunyai tegangan lebih rendah.

\section{URAIAN PENELITIAN}

Penyeimbang Baterai Berbasis Dual Inductor adalah sebuah alat penyeimbang (balancer) tegangan baterai jenis cell to pack yang terdiri dari dua buah induktor, empat saklar frekuensi tinggi, diode serta sebuah flying capacitor yang berfungsi untuk mentransfer energi dari satu sel baterai menuju ke seluruh sel baterai dalam satu modul[2].

Rangkaian dari Penyeimbang Baterai Berbasis Dual Inductor dapat dilihat pada Gambar 1. 


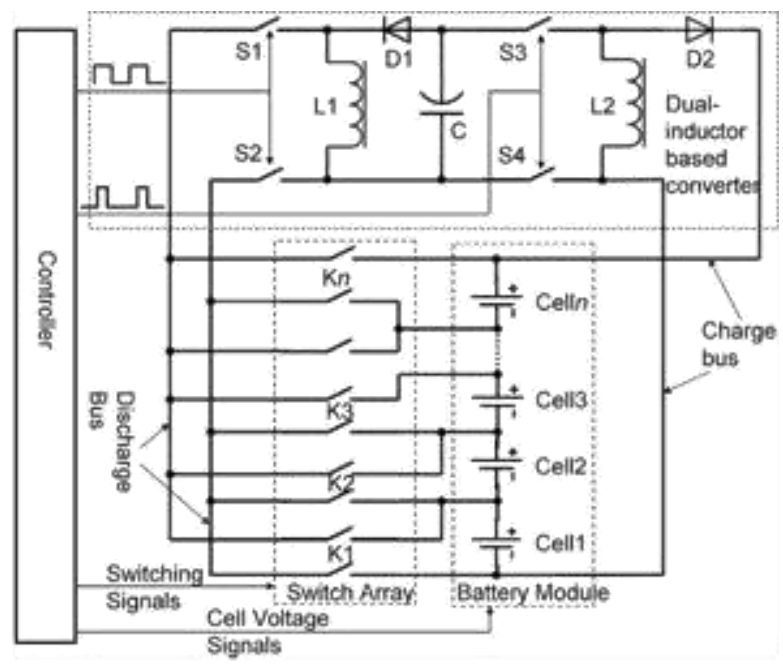

Gambar 1 Penyeimbang Baterai Berbasis Dual Inductor

Komponen utama pada alat ini adalah converter berbasis dual induktor. Untuk mempermudah, rangkaian dari converter berbasis dual induktor dapat dilihat pada Gambar 2.

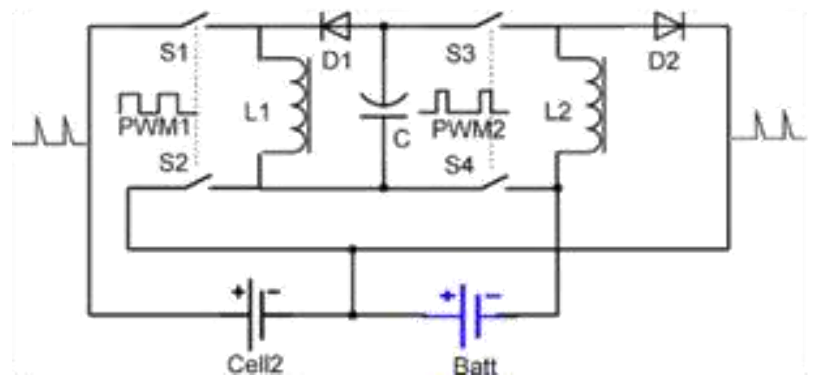

Gambar 2 converter berbasis dual induktor

Prinsip kerja dari adalah converter berbasis dual induktor dibagi menjadi empat fase[1].

\section{Fase I}

Arah aliran arus fase pertama dapat dilihat pada Gambar 3. Pada fase pertama $\left(0 \sim \mathrm{t}_{\mathrm{on} 1}\right) \mathrm{S}_{1}$ dan $\mathrm{S}_{2}$ on sehingga sel 2 mengisi induktor $\mathrm{L}_{1}$ besarnya arus pada fase pertama dapat dihitung dengan persamaan

$$
I_{1}(t)=\frac{V_{\text {sel2 }}}{R_{1}}\left(1-e^{\frac{R_{1}}{L_{1}} t}\right)
$$

Dimana Vsel2 adalah terminal dari sel2, R1 adalah resistansi dari induktor dan L1 adalah induktansi dari L1. Dalam keadaan normal, nilai R1 sangat kecil sehingga dapat diabaikan menjadi[1].

$$
I_{1}(t)=\frac{V_{\text {sel2 }}}{L_{1}} t
$$

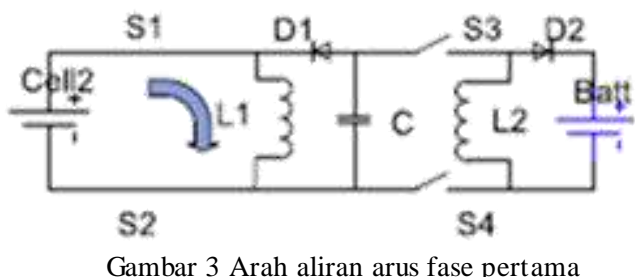

2. Fase II

Fase II adalah periode saat $t_{o n 1} \sim\left(t_{o n 1}+t_{D}\right)$ dimana semua saklar off sedangkan arus $\mathrm{I}_{1}$ menuju ke kapasitor $\mathrm{C}$ seperti pada Gambar 4. Diode D1 digunakan untuk menghindari condisi resonansi dari $\mathrm{C}$ dan $\mathrm{L}_{1}[1]$.

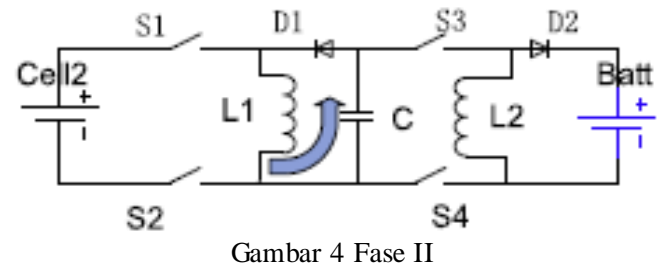

3. Fase III

Fase ketiga terjadi pada saat $\left(t_{o n 1}+t_{D}\right)$ sampai dengan $\left(t_{o n 1}+\right.$ $\left.t_{D}+t_{o n 2}\right)$. Pada fase ini saklar S3 dan S4 off. Pada fase ketiga kapasitor akan mengalirkan energi ke L2 sehingga terjadi resonansi antara C dengan L2[1]. Periode dari resonansi LC dapat dihitung dengan persamaan.

$$
T_{L C 2}=2 \pi \sqrt{L_{2} C}
$$

Agar C bekerja pada mode non zero current, maka

$$
T_{L C 2} / 4>t_{\text {on } 2}
$$

Sehingga nilai minimum kapasitor adalah

$$
C_{\text {min }} \geq \frac{4 t_{o n 2}^{2}}{\pi^{2} L_{2}}
$$

Jika kapasitas C terlalu besar maka pada L1 akan terjadi saturasi magnetik sehingga mengurangi efisiensi[1]. untuk menghindari hal tersebut maka nilai $\mathrm{C}_{\max }$ ditentukan dengan persamaan

$T_{L C 1} / 4<\left(2 t_{D}+t_{\text {on } 2}\right)$

Dimana

$T_{L C 1}=2 \pi \sqrt{L_{1} C}$

Sehingga didapatkan

$C_{\max }<\frac{4\left(2 t_{D}+t_{\text {on } 2}\right)^{2}}{\pi^{2} L_{1}}$

4. Fase IV

Fase keempat berlangsung pada saat $\left(t_{\text {on } 1}+t_{D}+t_{\text {on } 2}\right)$ hingga T. Pada fase ini S3 dan S4 off sementara S1 dan S2 on. Aliran arus dapat dilihat pada Gambar 5. L2 mengisi modul baterai 
sementara sel 2 kembali mengisi L1. Arus pengisian dari L2 ke modul baterai adalah

$I_{2}(t)=-\frac{V_{\text {batt }}}{R_{2}}+e^{\frac{R_{2}}{L_{2}} t}\left(I_{M 2}+\frac{V_{\text {batt }}}{R 2}\right)$

Dimana $\mathrm{V}_{\text {batt }}$ adalah tegangan terminal dari modul baterai, L2 adalah induktansi L2, $\mathrm{R}_{2}$ adalah resistansi dari induktor L2 dan $I_{M 2}$ adalah arus L2 saat $\left(t_{o n 1}+t_{D}+t_{o n 2}\right)$. Dalam keadaan normal, resistansi dari induktor L2 sangat kecil sedangkan nilai L1 sama dengan nilai L2 sehingga persamaan (2.14) dapat disederhanakan menjadi[1].

$I_{2}(t)=I_{M 2}-\frac{V_{b a t t}}{L} t$

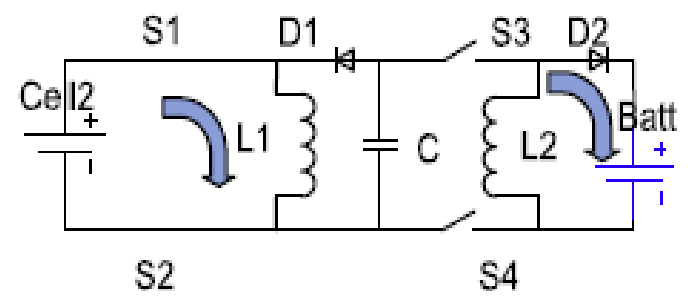

Gambar 5 Aliran arus pada fase IV

\section{DESAIN, SIMULASI DAN IMPLEMENTASI}

\section{A. Blok Diagram}

Perancangan dan pembuatan penyeimbang baterai berbasis dual induktor menggunakan mikrokontroler ATMEGA8 sebagai kontroler utama dan pembangkit pulsa PWM mengacu pada blok diagram yang ditunjukkan pada Gambar 6. Input dari alat ini adalah tegangan dari salah satu sel pada modul baterai yang dipilih oleh kontroler utama melalui relay. Tegangan tersebut dinaikkan oleh konverter dual 274nduktor menjadi setara dengan tegangan total dari modul baterai yang kemudian dimasukkan kembali ke modul baterai melalui charge bus.

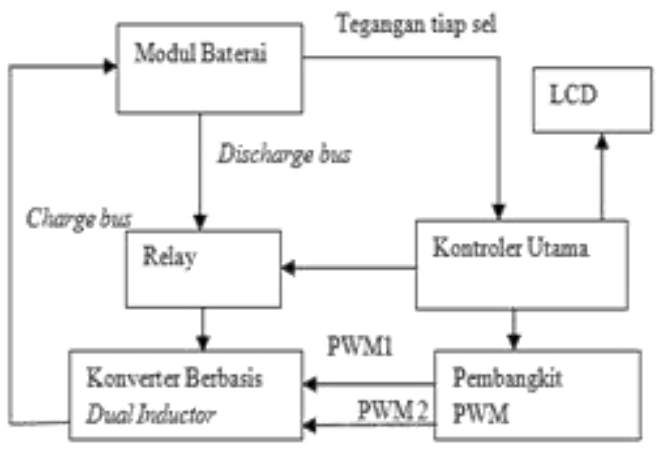

Gambar 6 Blok Diagram Sistem

\section{B. Perancangan Kontroler Utama}

Kontroler utama dari penyeimbang baterai terdiri dari mikrokontroler ATMEGA8, rangkaian pembagi tegangan dan LCD. Mikrokontroler akan memonitor tegangan tiap sel baterai kemudian membandingkan sel yang lain sehingga didapatkan sebuah sel dengan tegangan tertinggi. Flow Chart dari kontroler dapat dilihat pada Gambar 7.

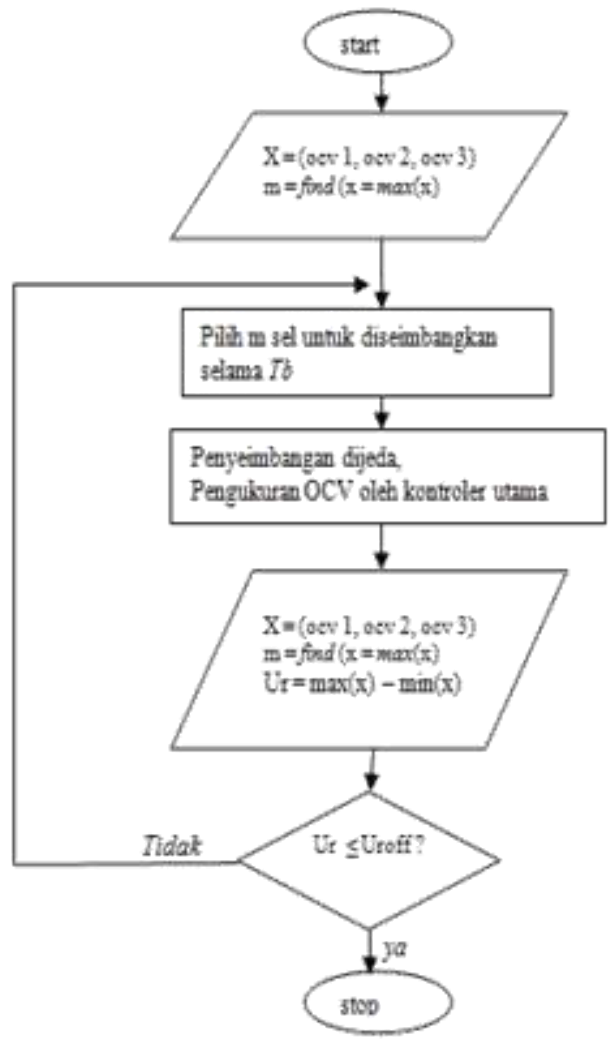

Gambar 7 Flow Chart Kontroler Utama

\section{Perancangan Pembangkit Pulsa PWM}

Pembangkit pulsa pwm terdiri dari sebuah mikrokontroler ATMEGA8 yang diprogram untuk membangkitkan pulsa PWM dengan duty cycle PWM $175 \%$ dan PWM $2=76 \%$ dimana PWM 2 adalah inverting dari PWM 1. Bentuk gelombang PWM1 dan PWM2 ditunjukkan pada Gambar 8 Frekuensi PWM ditentukan dengan persamaan

$$
f_{P W M}=\frac{f_{\text {clk }}}{510 \times \text { prescaler }}
$$

Dimana

$f_{P W M}=$ frekuensi pwm

$f_{\text {clk }} \quad=$ frekuensi clock

prescaler $=$ faktor pembagi

dengan frekuensi clock sebesar $12 \mathrm{Mhz}$ maka didapatkan frekuensi PWM sebesar

$$
\begin{aligned}
& f_{P W M}=\frac{12000000}{510 \times 1} \\
& f_{P W M}=23,5 \mathrm{Khz}
\end{aligned}
$$




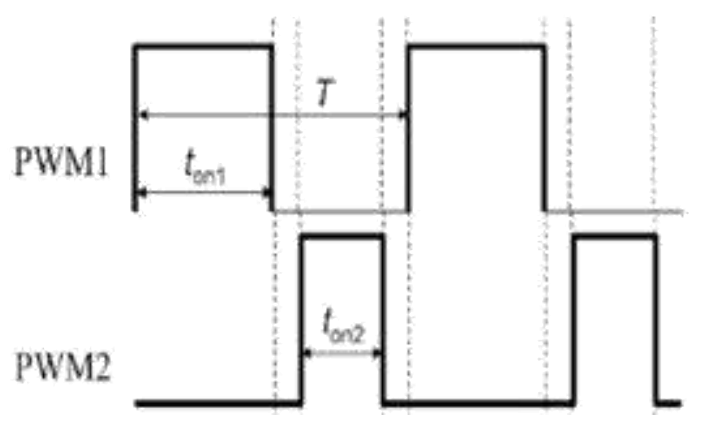

Gambar 8 Pulsa PWM 1 dan PWM 2

\section{Menghitung Nilai Induktor}

Pada Konverter Berbasis Dual Inductor, nilai dari induktor 1 sama dengan nilai induktor 2 dimana

$$
\begin{aligned}
& f_{\text {switch }}=23,5 \mathrm{kHz} \\
& T=42,5 \mathrm{us} \\
& \mathrm{D} 1=75 \% \\
& T_{\text {on } 1}=31,87 \mathrm{us} \\
& \mathrm{I}_{\mathrm{ml}}=1,5 \mathrm{~A}
\end{aligned}
$$

Dengan menggunakan persamaan $(2,7)$ maka didapatkan

$L=\frac{V s e l}{I m} t_{\text {on } 1}$

$L=\frac{4,2}{1,5} 31,8$ us

$L=89,23 U h \approx 100 U h$

\section{E. Menghitung nilai kapasitor}

$L \quad=100 \mathrm{Uh}$

$T_{\text {on1 }}=31,87 \mathrm{us}$

$2 T_{D}+T_{O N 2}=42,5-31,87$

$2 T_{D}+T_{O N 2}=10,63 \mathrm{us}$

Dengan menggunakan rumus persamaan (2,13), maka nilai kapasitas kapasitor maksimum adalah

$C_{\max }=\frac{4(10,63 u s)^{2}}{3,14^{2} \times 100 u H}$

$C_{\max }=0,46 \mathrm{Uf} \approx 0,47 \mathrm{Uf}$

\section{F. Perancangan Swtich S1 dan S2}

Saklar frekuensi tinggi SI dan S2 pada rangkaian konverter ini beroperasi pada tegangan rendah yaitu $4 \mathrm{~V}$, sehingga mosfet tidak dapat digunakan karena tegangan treshold minimum dari mosfet tidak terpenuhi. Oleh karena itu saklar S1 dan S2 menggunakan transistor sebagai switch frekuensi tinggi karena transistor bekerja berdasarkan arus pada kaki basis.

$$
\begin{aligned}
& I b=\frac{I c}{h f e} \\
& R b=\frac{V c e-0,6}{I b}
\end{aligned}
$$

$I b=$ Arus basis

$I c=$ Arus colector

$R b=$ Hambatan pada kaki basis

$V c e=$ Tegangan colector - emitor

$h f e=$ nilai penguatan arus $\mathrm{DC}$

Transistor TIP 2955 dan TIP3055 mempunyai nilai hfe minimum 20 sehingga nilai $R b$

$I b=\frac{2}{20}$

$I b=0,1 A$

$R b=\frac{4,2-0,6}{0,1}$

$R b=36 \Omega \approx 33 \Omega$

\section{G. Simulasi Konverter Berbasis Dual Inductor}

Karena keterbatasan software simulasi PSIM maka, simulasi hanya dapat dilakukan pada modul Konverter Berbasis Dual Inductor saja. Skema simulasi dari Konverter Berbas is Dual Inductor ditunjukkan pada Gambar 9

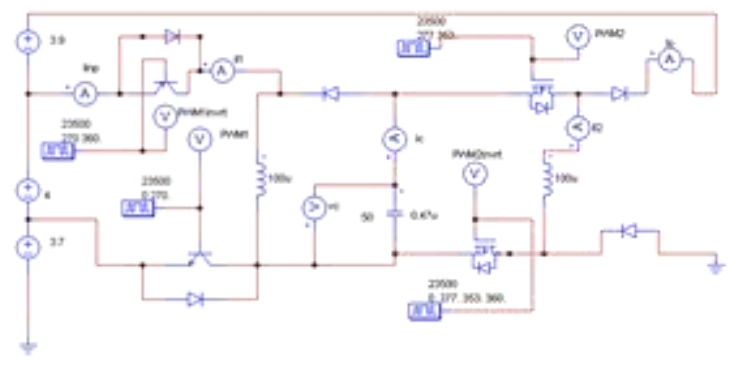

Gambar 9 Skema Simulasi Konverter Berbasis Dual Inductor

Antara PWM 1 dan PWM2 terdapat jeda waktu $\mathrm{T}_{\mathrm{D}}$ sebesar $1 U s$. Jeda waktu ini berfungsi untuk membuat flying capacitor berada pada mode non zero current. Dimana arah tegangan kapasitor tidak berubah sedangkan arus kapasitor tidak berhenti di titik nol seperti pada gambar10, sehingga kapasitor dapat bekerja sebagai buffer L1. Arus pada induktor L1 akan berpindah ke induktor L2. Hal ini menyebabkan arus peak dari induktor L1 sama dengan arus peak dari induktor L2 Bentuk gelombang hasil simulasi ditunjukkan pada gambar 11.

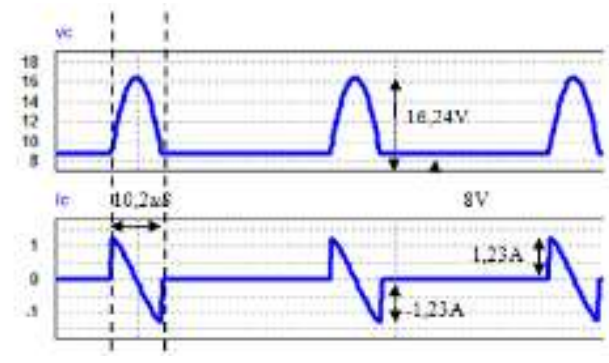

Gambar 10 Arus dan Tegangan Kapasitor

Dimana 


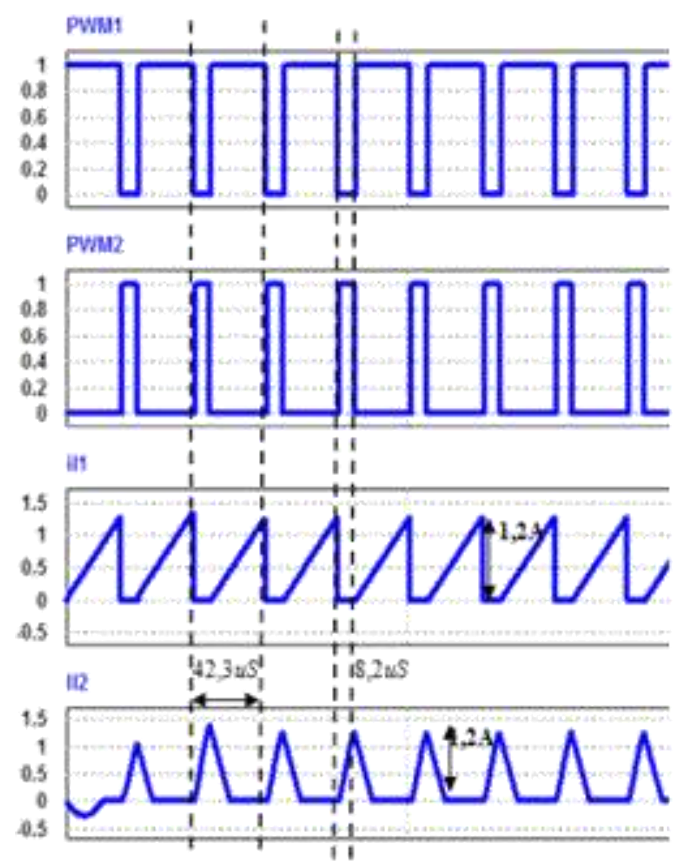

Gambar 11 Bentuk gelombang hasil simulasi

\section{H. Implementasi Konverter Berbasis Dual Inductor}

Implementasi dari Penyeimbang Baterai Berbasis Dual Inductor disesuaikan seperti pada Gambar 6. Implementasi dari Penyeimbang Baterai Berbasis Dual Inductor dapat dilihat pada gambar 12 sedangkan komponen yang digunakan dapat dilihat pada tabel 1

Tabel 1 Spesifikasi Komponen

\begin{tabular}{cc}
\hline \hline Komponen & Nilai \\
\hline Induktor L1 & $100 u H$ \\
Induktor L2 & $100 u H$ \\
Kapasitor & $0,47 u F$ \\
N-Mosfet & Irf 540 \\
P-Mosfet & Irf 9830 \\
Transistor PNP & TIP 2955 \\
Transistor NPN & TIP 3055 \\
Diode & 1N5822 \\
Driver Mosfet & TLP 250 \\
\hline \hline
\end{tabular}

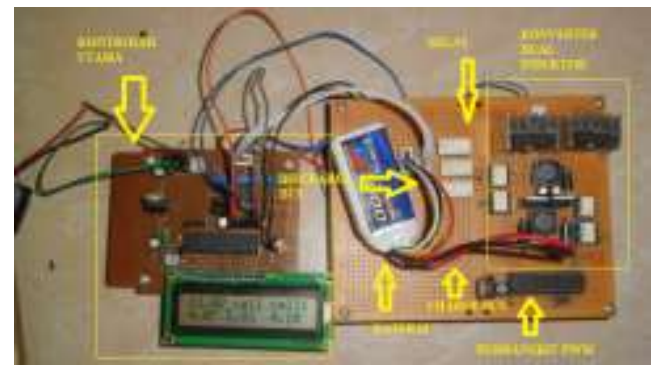

Gambar 12 Implementasi dari Penyeimbang Baterai Berbasis Dual Inductor

\section{PENGUJIAN}

Pengujian yang dilakukan adalah pengujian, arus induktor L1, arus induktor L2, tegangan kapasitor, arus kapasitor, dan pengujian terhadap tiga kondisi baterai lithium polymer yang berbeda. Pengujian dilakukan sebagaimana disebutkan pada Tabel 2 berikut.

Tabel 2 Kondisi Pengujian Penyeimbang Baterai Berbasis Dual Inductor.

\begin{tabular}{ll}
\hline \hline parameter & Kondisi \\
\hline Frekuensi & $23,53 \mathrm{kHz}$ \\
PWM1 & $75 \%$ \\
PWM2 & $24 \%$ \\
$T_{B}$ & $10 \mathrm{~S}$ \\
Baterai & Li-Po 3 sel $1600 \mathrm{mAh}$ \\
Status sel & Sel1 : 3,93 V; sel2 :4V ; sel3: $3,82 \mathrm{~V}$ \\
Status balancer & Discharge bus terhubung ke sel 2 \\
\hline \hline
\end{tabular}

A. Pengujian Induktor PWM1, PWM2, IL1, IL2, VC, dan IC Bentuk gelombang hasil pengujian dapat dilihat pada gambar 13 .

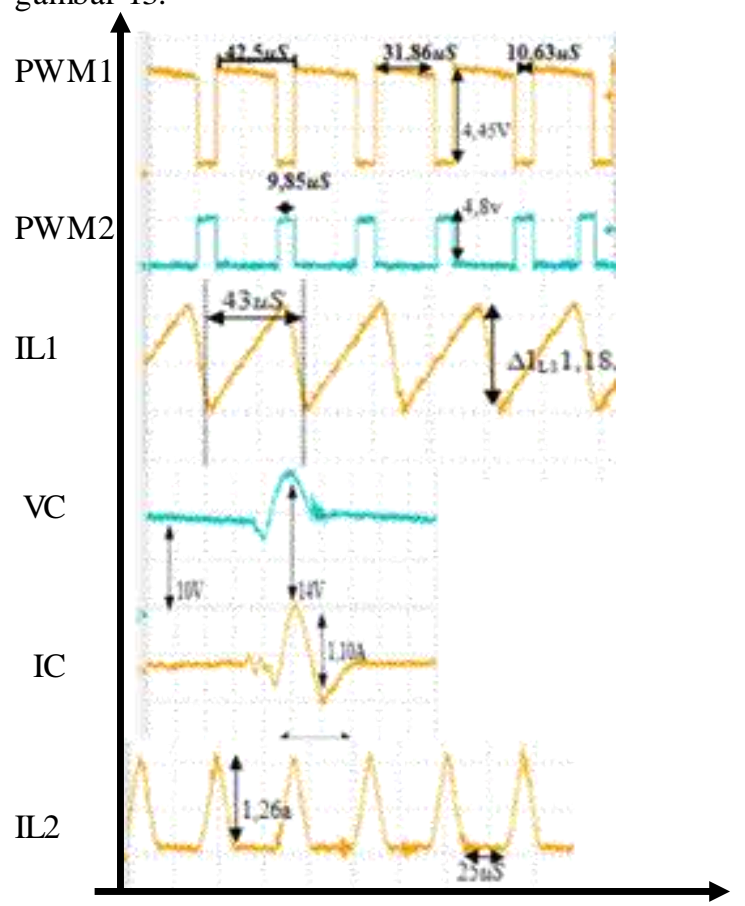

Gambar 13 Bentuk gelombang hasil pengujian

Di dalam simulasi, arus induktor L1 dapat menyentuh angka nol sedangkan pada implementasi arus induktor selalu lebih dari nol. Hal ini disebabkan karena dalam simulasi dan perhitungan, induktor diasumsikan ideal sedangkan pada implementasi komponen yang digunakan tidak ideal.. polaritas tegangan pada kapasitor tidak berubah, hal ini menunjukkan bahwa kapasitor bekerja pada mode buffer. Induktor L2 bekerja berdasarkan PWM2. Ketika $t_{2}$ pada PWM2 on, maka induktor L2 charging. Ketika $t_{2}$ off, maka induktor L2 mengisi baterai. Pada simulasi, Arus yang melalui induktor L2 sama dengan arus yang melalui induktor L1, sedangkan pada implementasi arus induktor L2 berbeda dengan arus pada L1. Hal ini dikarenakan komponen yang dipakai pada alat ini tidak ideal. Pengujian Terhadap Kondisi Baterai:

\section{Kondisi dua baterai under voltage}

Pengujian terhadap Kondisi dua baterai undervoltage dapat dilihat pada gambar 14 . 


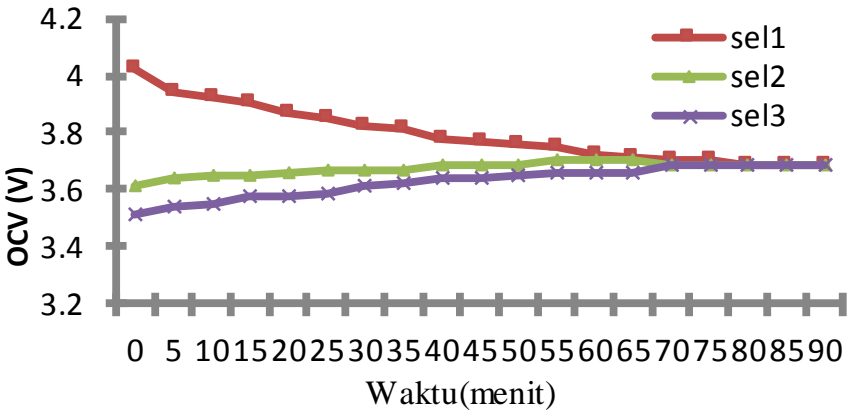

Gambar 14 Pengujian terhadap Kondisi dua baterai under voltage

Diketahui bahwa untuk menyeimbangkan tegangan dari dua dari tiga sel yang under voltage dibutuhkan waktu 70 menit. Kedua sel baterai yang mempunyai OCV awal 3,61V dan $3,51 \mathrm{~V}$ meningkat menjadi $3,69 \mathrm{~V}$ sedangkan pada sel baterai yang mempunyai OCV awal $4,02 \mathrm{~V}$ menurun menjadi $3,7 \mathrm{~V}$

\section{Kondisi satu sel baterai under voltage}

Pengujian terhadap Kondisi satu baterai under voltage dapat dilihat pada gambar 15 .

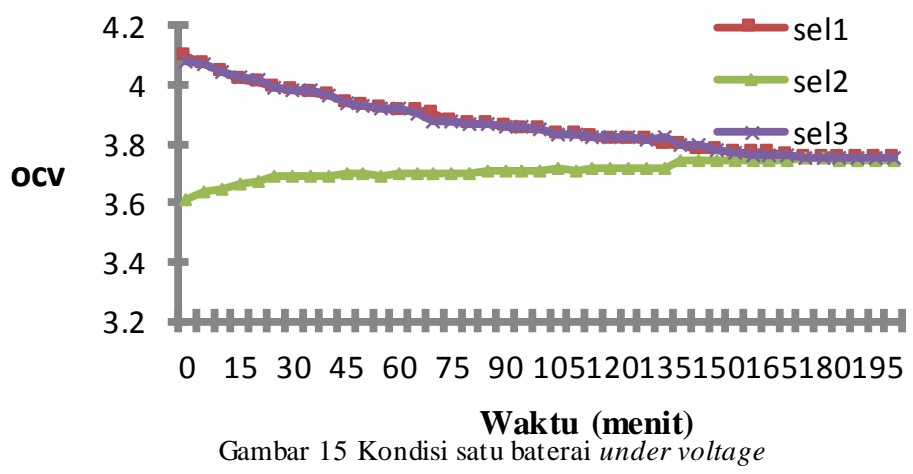

Dari Gambar 15 diketahui bahwa proses penyeimbangan pada kondisi kedua membutuhkan waktu lebih lama dibandingkan dengan proses penyeimbangan pada kondisi 1 dimana proses penyeimbangan membutuhkan waktu 175 menit. Tegangan sel 2 baterai awal 3,61 meningkat dengan cepat hingga 3,7v dalam waktu 40 menit. Kemudian peningkatan tegangan berjalan lebih lambat hingga mencapai $3,75 \mathrm{~V}$ pada menit ke175.

\section{Kondisi ketiga sel baterai normal}

Pengujian terhadap Kondisi ketiga sel baterai normal dapat dilihat pada gambar 16. Dari gambar 4.8 diketahui bahwa proses penyeimbangan memerlukan waktu yang lebih cepat dibandingkan dengan kondisi 1 dan kondisi 2. Hal ini dikarenakan perbedaan tegangan antar sel yang kecil sehingga ketiga sel baterai mempunyai tegangan yang seimbang dalam waktu 35 menit.

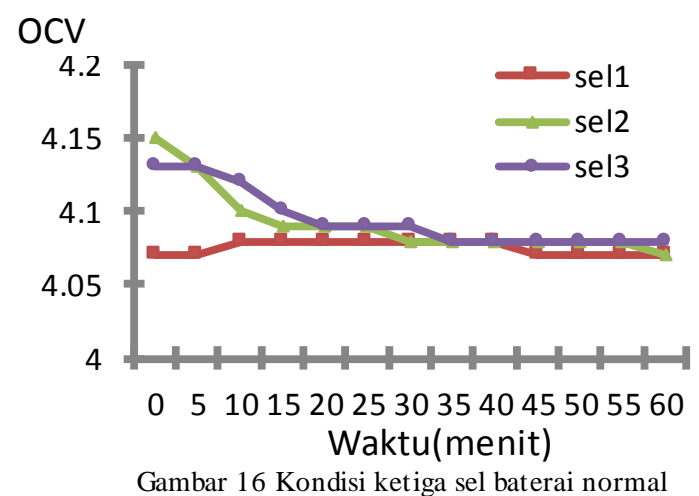

\section{KESIMPULAN}

Berdasarkan analisis data, hasil simulasi dan pengujian implementasi alat Penyeimbang Baterai Berbasis Dual Inductor, dapat disimpulkan beberapa hal sebagai berikut

1. Penyeimbang Baterai Berbasis Dual Inductor dapat digunakan pada battery pack dengan tingkat ketidakseimbangan yang tinggi hingga $0,5 \mathrm{~V}$.

2. Waktu penyeimbangan tegangan OCV baterai tergantung dari perbedaan tegangan antar sel baterai. Semakin besar perbedaan tegangan antar sel baterai maka semakin lama proses penyeimbangannya.

3. Tegangan total dari battery pack setelah proses penyeimbangan lebih kecil dibandingkan dengan tegangan total dari battery pack sebelum proses penyeimbangan. Hal ini dikarenakan terjadi loses saat proses penyeimbangan dan akibat dari efisiensi pengisisan dari baterai.

\section{DAFTAR PUSTAKA}

[1] Dai, Haifeng., Wei, Xuezhe., Sun, Zechang., dan Wang, Daizhuang., "A novel dual-inductor based charge equalizer for traction battery cells of electric vehicles", Electrical Power and Energy Systems, Shanghai, 2014.

[2] Xu, Jun., Li, Siqi., Mi, Chris., Chen, Zheng dan Cao, Binggang., "SOC Based Battery Cell Balancing with a Novel Topology and Reduced Component Count", energies ISSN 1996-1073, 2013 